\begin{tabular}{|l|l|}
\hline Postprint Version & 1.0 \\
\hline Journal website & $\underline{\text { http://onlinelibrary.wiley.com/doi/10.1002/ibd.22921/abstract }}$ \\
\hline Pubmed link & $\underline{\text { http://www.ncbi.nlm.nih.gov/pubmed/22374877 }}$ \\
\hline DOI & $10.1002 /$ ibd.22921 \\
\hline
\end{tabular}

This is a NIVEL certified Post Print, more info at http://www.nivel.eu

\title{
Labor participation among patients with inflammatory bowel disease
}

\author{
JUSTINE E. NETJES MA*, MieKE RIJKEN PHD
}

\begin{abstract}
Background: The aims of the present study are twofold. First, to describe labor participation rates of people with inflammatory bowel disease (IBD) in the Netherlands compared with the total Dutch population and to people with chronic illness in general. Second, to explore differences in labor participation among IBD patients and assess the potential impact of a number of characteristics of IBD patients on labor participation.

Methods: Data were obtained from a nationwide survey of individuals with IBD in the Netherlands. In all, 1115 respondents completed the survey. Univariate, bivariate, and multinomial logistic regression analysis were conducted to identify factors predicting the number of hours worked by IBD patients.

Results: People with IBD do not participate less often in the labor market compared with the total Dutch population age 15 to 64 . However, male patients age 45 to 64 less often have a fulltime job compared with age- and gender-matched reference groups from the general population. People with IBD are more likely to participate in the labor market than people with chronic illness in general. Gender, age, duration of illness, having a stoma or pouch, comorbidity, vitality, pain, and perceived personal control appear to be significant predictors of the number of hours worked.

Conclusions: People with IBD in the Netherlands are as often employed as the general population, but among some gender/age categories fewer people work fulltime. Besides sociodemographic and illness characteristics, the perception of personal control over the illness explains differences in the number of hours worked. Strengthening IBD patients' control perceptions deserves attention. (Inflamm Bowel Dis 2012;)
\end{abstract}

Around 1.4 million people in the United States and 2.2 million people in Europe suffer from inflammatory bowel diseases (IBD). ${ }^{1}$ The two most commonly reported inflammatory bowel diseases are Crohn's disease (CD) and ulcerative colitis (UC). In the Netherlands, $\approx 57,000$ people have an IBD $^{2}$ out of a total population of $16,358,000,{ }^{3}$ i.e., 3.5 per 1000 inhabitants.

IBD is characterized by an intermittent course, with periods of relapse and remission. Patients suffering from IBD have gastrointestinal problems that characteristically result in diarrhea and abdominal cramps. These problems can be accompanied by, for example, fatigue and a deterioration in physical condition. Because of the symptom burden and the unpredictable course of the illness, IBD can impact many different aspects of life. Until now, most research among IBD patients has focused on aspects of quality of life $\mathrm{e}^{4-8}$; less is known about the consequences of IBD for social participation, in particular participation in the labor market. Labor market participation can be important for many reasons. Besides the economic benefits, labor 
market participation has been found to improve social status, feelings of individual identity, and wellbeing. ${ }^{9}$

It is not easy to obtain an overview of the relationship between IBD and employment based on the results of previous studies. ${ }^{10}$ Some studies report no difference in employment rate between IBD patients and people without IBD. ${ }^{11},{ }^{12}$ However, these studies only examined people with $\mathrm{CD}$. In contrast, other studies report differences. For example, Boonen et $\mathrm{al}^{13}$ found in a Dutch study that the rate of labor participation was lower and work disability was higher among IBD patients than among people without IBD. Similarly, in their literature review of the education and employment status of IBD patients, Marri and Buchman ${ }^{10}$ found a higher nonparticipation rate in the labor force among people with IBD. Regarding the number of hours worked, a recent study by Gay et $\mathrm{al}^{14}$ in the UK showed that more than half of their respondents with IBD had to reduce their working hours as a result of their illness, and nearly one-third stated that they would work longer hours if they did not have IBD. Some other studies report variation in labor participation among IBD patients, depending on the phase of the disease or the severity of disease symptoms or burden. ${ }^{15}{ }^{16}$ We also expect characteristics of IBD patients to be related to labor participation. We know, for example, that in the general population demographic characteristics such as gender and age are related to labor participation and we likewise expect to find such differences among IBD patients. Furthermore, it is possible that the degree of pain, or fatigue, influences labor participation among IBD patients. For example, Baanders et $\mathrm{al}^{17}$ showed that chronically ill people who were employed reported less pain and fatigue compared with fully work-disabled chronically ill. With the aim of improving our understanding of the labor market status of people with IBD, our study takes a two-pronged approach. First, we describe labor participation by IBD patients in the Netherlands and compare this with labor participation rates of the total Dutch working population and of people with chronic illness in general. Second, we explore differences in labor participation among IBD patients and assess the potential impact of a number of characteristics of IBD sufferers on (the extent of) labor participation. In this respect, we focus on sociodemographic and disease characteristics, perceived health status (fatigue, pain, and mental health), psychological characteristics, and social characteristics. Specifically, we formulated the following research questions: 1) What is the labor participation rate among IBD patients in the Netherlands and how does it compare with the labor participation rate among the total Dutch population (age 15 to 64 years) and among people with chronic illness in general? 2) Why do some people with IBD work more hours per week in a paid job than other people with IBD, e.g., which individual characteristics account for these differences in labor participation?

\section{MATERIALS AND METHODS}

\section{Data and Study Population}

Data were obtained from a nationwide survey of IBD patients in the Netherlands. Since a national registry of people diagnosed with IBD does not exist, a representative sample of IBD patients cannot be easily drawn and population characteristics are not fully known. Therefore, we decided to make use of a number of recruitment methods to compile our sample, assuming that these methods might complement each other and thus provide maximum coverage of the target population of this study.

We started by placing a notice calling for participation in an online survey on two websites: the website of the Dutch Crohn and Colitis research foundation and the website of the national Crohn and Colitis patient association in the Netherlands. In the notice on the websites, people with IBD, age 15 to 64 years, who reported having visited a general practitioner or medical specialist because of IBD during the past year were invited to participate in the survey. The information on the websites stated that the aim of the study was to gain more insight into the "social situation" of IBD patients and that survey questions related to whether or not IBD patients performed paid work, and to what extent health (e.g., fatigue) played a role in this respect. The notice was also mentioned in the online newsletter of the patient association (October 2010). In addition to this, members of the patient association received an email containing notification about the survey. Second, IBD patients who attended an information meeting about IBD in eight university hospitals throughout the Netherlands were approached with an information leaflet and registration form. Patients treated in nonteaching (regional) hospitals were also invited to these meetings. Third, we made use of an already existing nationwide panel study of people with (medically diagnosed) chronic diseases: the National Panel of People with Chronic illness or Disability (NPCD). ${ }^{18}$ People diagnosed with IBD (ICPC 
code D94) age 15 to 64 years who participated in NPCD were approached with a request to participate in an (additional) survey, specifically for patients with IBD.

In total, we reached 1369 individuals, of whom 1115 (81.4\%) actually completed (the internet or postal version of) the questionnaire for this study.

\section{Survey}

The survey was conducted in December 2010 and contained (self-composed and validated) questions about labor participation, sociodemographic characteristics, disease characteristics, perceived health status, psychological characteristics, and social characteristics.

In accordance with the definition by Statistics Netherlands, ${ }^{19}$ labor participation was defined as currently having paid work for at least 12 hours per week (hpw). Further classification of hours per week worked was also based on the Statistics Netherlands definition: 0 hpw, 1-11 hpw, 12-19 hpw, 20-34 hpw, and 35 hpw or more (considered as working fulltime).

The sociodemographic characteristics included were gender, age, education level, and marital status. Education level referred to the highest level of education completed and was divided into three categories: low (no, primary or lower secondary, and vocational education), middle (intermediate secondary and intermediate vocational education), and high (higher vocational education and university). Marital status was dichotomized as: married/cohabiting versus single (including divorced or widowed).

The following disease characteristics were included: IBD type, illness duration, currently under medical treatment by a general practitioner (GP) (or specialist) for IBD, hospitalization due to IBD during the last 12 months, (currently) having a stoma, (currently) having a pouch, (currently) using IBD-related medication prescribed by a GP (or specialist), (currently) using prescribed dietary products and presence of comorbidity. The IBD types distinguished were CD, UC, and "other" types of IBD (for example, unspecified IBD). Illness duration was estimated by subtracting the reported year of diagnosis from the year 2011. All treatment characteristics mentioned above were assessed by self-report questions, each with answering options Yes or No. Comorbidity was dichotomized as no other chronic disease versus one or more other chronic diseases.

Perceived health status was assessed on three scales of the RAND- $36^{20},{ }^{21}$ : vitality (four items, $\alpha=0.86$ ), bodily pain (two items, $\alpha=0.82$ ), and mental health (five items, $\alpha=0.83$ ). A higher score indicates greater vitality, less bodily pain, or better mental health.

The following psychological characteristics were included: proactive coping and four dimensions of illness perceptions: perceived personal control, perceived control by medical treatment, illness concern, and illness coherence. In order to assess proactive coping (the ability to anticipate and deal with potential health threats before they occur), a validated questionnaire by Bode et $\mathrm{al}^{22}$ was used ( 21 items, $\alpha=0.90$ ), where a high score indicates better proactive coping skills. To assess the four dimensions of illness perception, we used the Brief Illness Perception Questionnaire. ${ }^{23}$ The four dimensions were all assessed by single items, where a higher score (1-10) indicates more perceived control, less concern, and more perceived illness coherence.

Social characteristics assessed related to (a lack of) perceived social support, measured on four scales of the Dutch Social Support List-Discrepancies (SSL-D). ${ }^{24}$ These four scales are: perceived lack of problemoriented emotional support, such as getting reassurance or comfort (six items, $\alpha=0.84$ ); self-esteem support, e.g., being trusted (four items, $\alpha=0.78$ ); instrumental support, e.g., practical household help (six items, $\alpha=0.72$ ); and informative support, e.g., getting constructive criticism (three items, $\alpha=0.68$ ). In these four scales a high score indicates a greater lack of support.

\section{Statistical Analysis}

STATA 10.0 (College Station, TX) was used to perform all statistical analyses. To correct for differences in gender, age, and type of disease distribution between sample characteristics and known characteristics of the Dutch IBD population, a weight factor was computed and applied to the statistical analyses conducted on the total sample of IBD patients. To construct the weight factor, we calculated the observed percentages of respondents within each cell (a total of 16 cells, resulting from the combination of two gender categories, five age categories, and two types of IBD: CD or UC) and compared these with the expected percentages in the 16 cells based on population data. Next, we computed the weight factor by dividing the expected percentages by the observed percentages in the sample, resulting in a weight factor with 16 values, ranging from 0.30 (for female respondents with CD age 25 to 34) to 3.65 (for male respondents with UC age 55 to $64)$. 
Descriptive statistics (percentages and 95\% confidence intervals, CI) were computed to describe the labor participation situation of IBD patients in comparison with the Dutch general population age 15 to 64 and the labor participation among people with chronic illness in general (derived from the nationwide NPCD panel study referred to above). Differences in labor participation rates between our sample and the two reference groups are considered as significant when the CIs of the sample do not overlap with the percentages (average and, in the case of the sample of chronic patients, also 95\% CI) found in the two reference groups.

In order to answer the second research question, we conducted bivariate and multivariate analyses. First, relationships between sociodemographic characteristics, disease characteristics, perceived health status, psychological characteristics, and social characteristics on the one hand and labor participation on the other, were assessed by means of cross-tabulation and chi-square tests, $t$-tests, and analysis of variance (ANOVA, one-way). Since we conducted 26 bivariate tests, we used $P=0.002$ (Bonferroni correction: $\alpha=0.05 / 26$ ) to conclude about any significant associations between patient characteristics and the number of hours worked.

Second, multinomial logistic regression analysis was performed to assess the significance of these characteristics to explain (part of) the variation in the number of hours worked per week by IBD patients. In this multivariate analysis, working full-time $(\geq 35 \mathrm{hpw})$ was designated as the reference category. For each characteristic (e.g., gender, age), b-coefficients, and relative risk ratios (RRR) were estimated, indicating how a unit's increase of the characteristics affects the coefficient of response, or ratio of the odds, of ending up in a specific group, versus working 35 hours or more. To decide on statistical significance, we used $P<$ 0.05 (unlike the bivariate tests mentioned above, these were not multiple separate tests.) Furthermore, we computed a likelihood ratio statistic (LR-test) for each category of characteristics (e.g., sociodemographic characteristics, disease characteristics). The LR-test is based on the likelihood ratio and expresses the probability of difference between each category compared with the full model.

\section{RESULTS}

\section{Sample Characteristics}

Of the total sample, $29 \%$ were male and $71 \%$ were female (Table ${ }^{1}$ ). The majority of respondents were younger than 45 (62\%). Only 7\% had a low level of education, whereas $47 \%$ had finished high vocational education or university. CD (53\%) appeared to be more prevalent in the sample than UC (43\%), while 5\% of the respondents had another or unspecified type of IBD. Table ${ }^{1}$ also shows some characteristics of the Dutch IBD population ${ }^{25}{ }^{26}$; information about the level of education is lacking. When comparing our sample with these population characteristics, it can be concluded that female patients and patients with CD were overrepresented in our sample. The age distribution was also slightly different from the age distribution of the population. Based on this information, we decided to compute a weight factor (see Statistical Analysis) and to correct our analyses by first weighting the data.

\section{[TABLE 1]}

\section{Labor Participation}

Table $^{2}$ shows the labor participation rates found in our sample and among the two reference groups (patients with chronic illness in general and the Dutch general population age 15 to 64).

\section{[TABLE 2]}

After weighting for gender, age, and IBD type, $72 \%$ of the IBD patients age 15 to 64 years appeared to work at least $12 \mathrm{hpw}$ (Table ${ }^{2}$ ). In the total Dutch population age 15 to 64 years, 67\% performed paid work for at least $12 \mathrm{hpw}$ in $2010^{19}$; while in the generic sample of patients with chronic illness the rate is $50 \%$.

As these three groups differ according to gender and age distribution, we also examined the labor participation rates of specific gender/age categories. The comparison of these categories shows a higher rate of labor participation among men and women with IBD age 45 to 54 years in comparison with patients of the same age with chronic illness in general. In addition, the estimated labor participation rate among women with IBD age 55 to 64 appears to be higher than among the generic sample of women with chronic 
illness age 55 to 64 . Table ${ }^{2}$ also shows that the participation rate of women age 15 to 24 years in the IBD sample is higher than that of the Dutch population controls.

\section{Number of Hours Worked per Week}

When considering the total sample, most people work 20 to $34 \mathrm{hpw}$ (34\%) or $35 \mathrm{hpw}$ or more (31\%), nearly one-quarter of the total sample works 0 hpw (24\%), a small group works less than 11 hpw or 12 to 19 hpw (respectively, 3\% and 8\%).

In Table ${ }^{3}$ we take a closer look at the number of hours worked per week by IBD patients in the labor force compared with the Dutch total labor force and the generic sample of patients with chronic illness. On average, people with IBD who participate in the labor market work fewer hours compared with the general Dutch working population, but more hours than working people with chronic illness in general. More than half the people in the general Dutch working population work fulltime (35 hpw or more), whereas this is the case for about $40 \%$ of the (self) employed people with IBD or (other) chronic illness.

\section{[TABLE 3]}

Since people with IBD differ from the total Dutch population with regard to the gender and age distribution, we specified the number of hours worked for each gender/age category in order to make a better comparison. In Table ${ }^{4}$ it can be seen that for most of the gender and age categories no significant differences exist between working IBD patients and the general Dutch working population, except for the hours worked by men age 45 to 54 and 55 to 64 . Male IBD patients age 45 to 64 work on average significantly fewer hours per week and less often in a fulltime job compared with men from the general Dutch working population.

\section{[TABLE 4]}

Because IBD seems to impact more the number of hours worked than on labor participation in general, we further explored individual differences between people with IBD working fulltime ( $\geq 35 \mathrm{hpw}$; reference category) and those working parttime or those who were not active in the labor market (not employed or working less than $12 \mathrm{hpw}$ ).

\section{Differences in Hours Worked Among IBD Patients}

Regarding the sociodemographic characteristics, Table ${ }^{5}$ shows that gender, age, and education level relate to the number of hours worked. For example, the group of people with IBD who are not employed or who work less than $12 \mathrm{hpw}$ (group 1) consists for the largest part of women, whereas group 4 (people with IBD who work fulltime) contains relatively more men. When considering disease characteristics, this also relates to the number of hours worked. The type of IBD, illness duration, having a stoma or pouch, and presence of comorbidity are all related to the number of hours worked. For example, the mean illness duration is significantly longer in group $1(<12 \mathrm{hpw})$ compared with group $4(\geq 35 \mathrm{hpw})$. With regard to the perceived health status, greater vitality, less pain, and better mental health are all related to working more hours per week. When considering psychological characteristics, we see that perceived personal control and illness concern are related to working a certain number of hours. None of the social (support) characteristics analyzed relate to working a certain number of hours a week.

\section{[TABLE 5]}

\section{Characteristics Predicting Hours Worked}

For each category of characteristics, we performed multinomial logistic regression analysis and compared the LR-test of each category with the full model, which contains all characteristics. The comparison shows that all categories make a significant contribution to explaining the number of hours worked. Of all categories, the sociodemographic model contributed the most, followed by the disease characteristics model, while the social support model made the smallest contribution.

Table ${ }^{6}$ shows which individual characteristics significantly explain the number of hours worked. The table shows that gender, age, IBD type (other type), duration of illness, having a stoma or pouch, comorbidity, vitality, pain, and perceived personal control are all significant predictors of the number of hours worked by people with IBD.

[table 6] 
Women are more likely to work less than 35 hpw than men. Furthermore, an older age increases the chance of not working fulltime. With regard to the type of IBD, having another type of IBD compared with $\mathrm{CD}$, decreases the relative risk of working 20-34 hpw, instead of working fulltime. The duration of illness, whether or not having a stoma or pouch, and the presence or absence of comorbidity also significantly predict the number of hours worked. For example, the relative risk of working less than 12 hpw, instead of working fulltime, increases for each year the illness lasts. Furthermore, for people with comorbidities the relative risk of working less than $12 \mathrm{hpw}$, instead of working fulltime, is greater than for people without comorbidities. Regarding the perceived health status, vitality and pain are significant predictors of the number of hours worked as well. Experiencing more vitality and less pain decreases the probability that one does not participate in the labor market. Lastly, the perception of personal control is a significant predictor: patients who experience more personal control are less likely to work fewer than $35 \mathrm{hpw}$.

\section{DISCUSSION}

This study shows that labor participation rates among IBD patients in the Netherlands are not lower than gender/age-specific labor participation rates of the general Dutch population. This finding is in line with the results of two previous studies, stating that there is no difference in employment rate among patients with CD compared with controls. ${ }^{11},{ }^{12}$ However, in two other studies labor participation rates of IBD patients were found to be lower. ${ }^{10},{ }^{13}$ It is difficult to compare our results with these other studies, owing to the different definitions used for labor participation, differences in age range, and the types of IBD studied. ${ }^{10}$ We also found that IBD patients are more likely to participate in the labor market than people with chronic illness in general. This difference is particularly noticeable among men and women with IBD age 45 to 54, of whom a greater proportion work compared with people with other chronic diseases.

While the employment rate among IBD patients is not lower than that of the general Dutch population, fewer IBD patients work fulltime. Whereas most (self) employed people with IBD work 20 to $34 \mathrm{hpw}$, the majority of the general Dutch working population work $35 \mathrm{hpw}$ or more. Looking more specifically at gender and age categories, especially male IBD patients age 45 to 64 work fewer hours per week compared with the general population of the same gender and age.

We subsequently examined factors that could explain differences in the number of hours worked among IBD patients. A variety of individual characteristics of IBD patients appeared to relate to the number of hours worked. Of the studied sociodemographic characteristics, gender, age, and education level were related to the number of hours worked. The differences in number of hours related to these characteristics are similar to those seen among general populations. ${ }^{19}$ In addition of the studied disease characteristics, illness duration, having a stoma or pouch, and presence of comorbidity are related to the number of hours worked. The degree of vitality, pain, and mental health also relate to working a certain number of hours, as are perceived personal control over the disease and illness concern. By analyzing all characteristics studied here simultaneously in a multivariate model, some appeared to be significant predictors of the number of hours worked, whereas others did not. Significant predictors were: gender, age, (other) type of IBD, duration of illness, having a stoma or pouch, comorbidity, vitality, bodily pain, and perceived personal control. We wish to mention that the total number of participants with another IBD type (not CD or UC) was small (5\% of the total sample). Therefore, the predictive value of having another type of IBD, compared with having $\mathrm{CD}$, should be interpreted with caution. The degree of vitality (or the opposite, fatigue) and pain experienced, as well as the perception of personal control over the disease are particularly interesting, as they might be factors to intervene on by supportive care, which is clearly not the case for the other characteristics with predictive value (gender, age, duration of illness, and presence of comorbidity). We are aware that we have to be careful here, since our study had a cross-sectional design, which does not allow causal interpretation of our findings. There may be a reciprocal relation between working a certain number of hours and the perceived health status or psychological characteristics of IBD patients. It is likely that patients who experience less vitality, more pain, and/or less personal control over the disease are more often unable to work fulltime. At the same time, it is possible that patients may feel more vital and experience less pain or more personal control because they succeed in working fulltime. Several psychological interventions have been developed with the aim of improving labor participation and patients' perceived autonomy in relation to various chronic diseases. ${ }^{27-29}$ Such interventions may be considered for subgroups of IBD patients as well. 
We found no other studies focusing on the relationship between individual characteristics of IBD patients and the number of hours worked in a paid job. Previous studies examined the impact of various characteristics of IBD patients on work disability or unemployment. Thus, strictly speaking, the results of our study cannot be compared with the results of these other studies. Nevertheless, we will discuss the results of some of these previous studies here in order to put our findings in a broader perspective.

Our finding that women with IBD work fewer hours than men with IBD correlates with, for example, studies by Feagan et $\mathrm{al}^{30}$ and Nordgren et al, ${ }^{31}$ who reported a higher likelihood of work disability in female than in male patients with CD; however, this contrasts with the findings of Ananthakrishnan et al. ${ }^{32}$ As van Kemenade et $\mathrm{al}^{33}$ found in a Dutch study, different coping styles between sexes provide a possible explanation for women working fewer hours than men. Other factors, which play a similar role in the general population, such as taking care of young children, may also explain why women with IBD work fewer hours than men. Our finding that age is a significant predictor for hours worked, where younger people with IBD work more hours per week than older people, is in line with the studies of Ananthakrishnan et $\mathrm{al}^{32}$ and Feagan et $\mathrm{al}^{30}{ }^{30}$ who found higher disability rates among older patients compared with younger patients. There are also some relevant other studies regarding our finding that education level relates to the number of hours worked. For example, Longobardi et $\mathrm{al}^{15}$ conclude that a low level of education was among the factors resulting in IBD patients being out of the labor force. However, Boonen et $\mathrm{al}^{13}$ found that the risk of being chronically work-disabled is higher among higher educated IBD patients.

Our findings about type of disease being related to hours worked are also supported by some other studies. For example, it was found that CD carries a greater risk of disability than UC. ${ }^{13},{ }^{34}, 35$

Lastly, our findings indicating that perceived personal control and illness concern are related to the number of hours worked are supported by Hoving et $\mathrm{al},{ }^{36}$ who found evidence in four studies that illness perceptions can play a role in labor participation of patients with somatic diseases or complaints.

Nonworking patients perceived their illness to have more serious consequences, attributed more symptoms to their disease, and expected their illness to last longer.

A strength of our study is that we looked beyond overall labor participation rates and specified the number of hours worked. Also, by using a number of different recruitment methods we were able to include a substantial group of respondents $(>1100)$, thereby improving the validity of our study and its results. Nevertheless, although we had a high response, $20 \%$ of the approached individuals did not respond. We do not have information about the characteristics of these nonrespondents, which is a limitation of the study.

Furthermore, it must be kept in mind that our data were not entirely randomly collected. Most of the respondents approached were familiar with the Dutch patient association of people with IBD. To reduce potential selection bias, we made use of other recruitment methods as well, e.g., recruitment via meetings organized in hospitals throughout the whole country and via a nationwide panel of people diagnosed with chronic diseases. Nevertheless, selection bias might have been present to some extent, since our sample included a higher number of female patients and patients with CD compared with reference data of the total Dutch population of IBD patients. In order to reduce the impact of these differences between our sample and the population data, we computed a weight factor, based on gender, age, and IBD type, and conducted analyses on the weighted data. Another limitation of our study may be that information on the type of IBD was based on patient self-report, which may be less precise than medical diagnoses. We tried to account for this by asking the respondents whether they were regularly visiting a GP or a medical specialist because of IBD.

Notwithstanding these limitations, we believe we can conclude that the rate of labor market participation among IBD patients in the Netherlands is not different from that of the total Dutch population, but that a smaller proportion of IBD patients work fulltime. By providing profiles of IBD patients working a certain number of hours per week, this study contributes to the specification of individual factors associated with labor participation. Several sociodemographic and illness characteristics relate to the number of hours worked by people with IBD, but perceived health and psychological characteristics of people with IBD, especially their perception of control over the disease, seem to be important as well. 


\section{REFERENCES}

1 Loftus E. Clinical epidemiology of inflammatory bowel disease: incidence, prevalence, and environmental influences. Gastroenterology. 2004; 126: 1504-1517.

2 Gommer AM, Poos MJJC. Figures inflammatory bowel diseases (prevalence, incidence and mortality) from VTV 2010. Bilthoven, the Netherlands: RIVM, http://www.nationaalkompas.nl/ Nationaal Kompas VolksgezondheidlGezondheid en ziektelZiekten en aandoeningenISpijsverteringsstelselIInflammatoire darmziekten. Accessed May 10, 2011.

3 Central Bureau of Statistics Netherlands. Online database Statline: "Kerncijfers bevolking 2007."

4 Russel MG, Pastoor CJ, Brandon S, et al. Validation of the Dutch translation of the Inflammatory Bowel Disease Questionnaire (IBDQ): a health-related quality of life questionnaire in inflammatory bowel disease. Digestion. 1997; 58: 282-288.

5 Bernklev T, Jahnsen J, Lygren I, et al. Health-related quality of life in patients with inflammatory bowel disease measured with the Short Form-36: psychometric assessments and a comparison with general population norms. Inflamm Bowel Dis. 2005; 11: 909-917.

6 Casellas F, López Vivancos J, Malagela JR. Previous experiences and quality of life in patients with inflammatory bowel disease during relapse. Rev Esp Enferm Dig. 2003; 95: 476-479.

7 Casellas F, Arenas JI, Baudet JS, et al. Impairment of health-related quality of life in patients with inflammatory bowel disease: a Spanish multicenter study. Inflamm Bowel Dis. 2005; 11: 488-496.

8 Wolters FL, Russel MG, Sijbrandij J, et al. Disease outcome of inflammatory bowel disease patients: general outline of a Europe-wide population-based 10-year clinical follow-up study. Scand J of Gastroenterol. 2006; 234: 46-54.

9 Waddell G, Burton AK. Is Work Good for Your Heath and Well-being? Norwich, UK: TSO; 2006.

10 Marri SR, Buchman AL. The education and employment status of patients with inflammatory bowel diseases. Inflamm Bowel Dis. 2005; 11: 171-177.

11 Mayberry MK, Probert C, Srivastava E, et al. Perceived discrimination in education and employment by people with Crohn's disease: a case control study of educational achievement and employment. Gut. 1992; 33: 312-314.

12 Thompson NP, Fleming DM, Charlton J, et al. Patients consulting with Crohn's disease in primary care in England and Wales. Eur J Gastroenterol Hepatol. 1998; 10: 1007-1012.

13 Boonen A, Dagnelie PC, Feleus A, et al. The impact of inflammatory bowel disease on labor force participation: results of a population sampled case-control study. Inflamm Bowel Dis. 2002; 8: 382-389.

Direct Link:

14 Gay M, et al. Crohn's, Colitis and Employment - From Career Aspirations to Reality. Hertfordshire, UK: Crohn's and Colitis UK; 2011.

15 Longobardi T, Jacobs P, Bernstein CN. Work losses related to inflammatory bowel disease in the United States: results from the National Health Interview Survey. Am J Gastroenterol. 2003; 98: 1064-1072.

16 Reinisch W, Sandborn WJ, Bala M, et al. Response and remission are associated with improved quality of life, employment and disability status, hours worked, and productivity of patients with ulcerative colitis. Inflamm Bowel Dis. 2007; 13: 1135-1140.

17 Baanders AN, Rijken PM, Peters L. Labour participation of the chronically ill. A profile sketch. Eur J Public Health. 2002; 12: 124-130.

18 Rijken M, van Kerkhof M, Dekker J, et al. Comorbidity of chronic diseases: effects of disease pairs on physical and mental functioning. Qual Life Res. 2005; 14: 45-55.

19 Statistics Netherlands 2011: Article, February, 212011 Arbeidsparticipatie naar leeftijd en geslacht: http://www.cbs.nl/nl-NL/menu/themas/arbeid-sociale-zekerheid/publicaties/arbeidsmarktvogelvlucht/structuur-arbeidsmarkt/2006-arbeidsmarkt-vv-participatie-art.htm. Accessed June 6, 2011.

20 Ware JE, Shebourne CD. The RAND-36 Short-Form Health Status Survey: I. Conceptual framework and item selection. Med Care. 1992; 30: 473-481.

21 van der Zee K, Sanderman R. Het meten van de algemene gezondheidstoestand met de RAND-36: Een handleiding. Groningen, the Netherlands: NCG 3; 1993.

22 Bode C, Thoolen B, de Ridder D. Het meten van proactieve Copingvaardigheden Psychometrische eigenschappen van de Utrechtse Proactieve Coping Competentie lijst (UPCC). Psychologie gezondheid. 2008; 36: 81-91.

23 Broadbent E, Petrie KJ, Main J, et al. The Brief IIIness Perception Questionnaire (BIPQ). J Psychosom Res. 2006; 60: 631-637. 
24 van Sonderen E. Het meten van sociale steun met de Sociale Steun Lijst-Interacties (SSL-i) en Sociale Steun Lijst Discrepanties (SSL-d): een handleiding. Groningen, the Netherlands: NCG 2; 1993.

25 Hoeymans N, Melse JM, Schoemaker CG. Gezondheid en determinanten Deelrapport van de VTV 2010: Van gezond naar beter. Bilthoven, the Netherlands: Rijksinstituut voor Volksgezondheid en Milieu; 2010.

26 Crohn and Colitis patient association in the Netherlands: CCUVN available at http://www.crohncolitis.nl/.

27 Jansen DL, Heijmans M, Rijken M, et al. The development of and first experiences with a behavioural self-regulation intervention for end-stage renal disease patients and their partners. J Health Psychol. 2011; 16: 274-283.

28 Petrie KJ, Cameron LD, Ellis CJ, et al. Changing illness perceptions after myocardial infarction: an early intervention randomized controlled trial. Psychosom Med. 2002; 64: 580-586.

29 Lorig KR, Ritter P, Stewart AL, et al. Chronic disease selfmanagement program. 2-year health status and health care utilization outcomes. Med Care. 2001; 39: 1217-1223.

30 Feagan BG, Bala M, Yan S, et al. Unemployment and disability in patients with moderately to severely active Crohn's disease. J Clin Gastroenterol. 2005; 39: 390-395.

31 Nordgren SR, Fasth SB, Oresland TO, et al. Long-term follow-up in Crohn's disease. Mortality, morbidity, and functional status. Scand J Gastroenterol. 1994; 29: 1122-1128.

32 Ananthakrishnan AN, Weber LR, Knox JF, et al. Permanent work disability in Crohn's disease. Am J Gastroenterol. 2008; 103: 154-161.

33 van Kemenade O, Roek M, Lagro-Janssen T. Een verkenning naar sekseverschillen in beloop, complicaties en de kwaliteit van leven. Huisarts Wetenschap. 2004; 47: 17-24.

34 Sellin J. Disability in IBD: the devil is in the details. Inflamm Bowel Dis. 2006; 16: 23-26.

35 Bernstein CN, Kraut A, Blanchard JF, et al. The relationship between inflammatory bowel disease and socioeconomic variables. Am J Gastroenterol. 2001; 96: 2117-2125.

36 Hoving JL, van der Meer M, Volkova AY, et al. Illness perceptions and work participation: a systematic review. Int Arch Occup Health. 2010; 83: 595-605.

\section{TABLES}

TABLE 1. Characteristics of Sample and Population of People with IBD Age 15 to 64 in the Netherlands

\begin{tabular}{|c|c|c|}
\hline \multicolumn{2}{|c|}{$\begin{array}{l}\text { Patients with IBD \% } \\
(95-\mathrm{CI})(N=1115)\end{array}$} & \multirow[t]{2}{*}{$\begin{array}{l}\text { IBD Population \% } \\
(95-C I)\left(N=39290^{\mathrm{a}}\right)\end{array}$} \\
\hline Gender & & \\
\hline Male & $29.4(26.8-32.2)$ & 48.6 \\
\hline Female & $70.6(67.8-73.2)$ & 51.4 \\
\hline \multicolumn{3}{|l|}{ Age $^{a}$} \\
\hline $15-24$ years & $6.7(5.4-8.4)$ & 6.4 \\
\hline 25-34 years & $28.8(26.2-31.5)$ & 17.1 \\
\hline $35-44$ years & $26.5(24.0-29.2)$ & 26.9 \\
\hline 45-54 years & $22.3(20.0-24.8)$ & 25.2 \\
\hline $55-64$ years & 15.7 (13.6-17.9) & 24.4 \\
\hline \multicolumn{3}{|l|}{ Education $^{\mathrm{b}}$} \\
\hline Low & $7.1(5.7-8.8)$ & unknown \\
\hline Middle & $47.0(44.0-49.9)$ & unknown \\
\hline High & $45.9(43.0-48.9)$ & unknown \\
\hline \multicolumn{3}{|l|}{ IBD Type ${ }^{c}$} \\
\hline Crohn's disease & $53.0(50.1-55.9)$ & 40.0 \\
\hline Ulcerative colitis & $42.8(38.9-44.7)$ & 60.0 \\
\hline Other & $5.2(4.1-6.7)$ & unknown \\
\hline \multicolumn{3}{|c|}{$\begin{array}{l}\text { a Sample } n=1112 . \\
\text { 'Sample } n=1099 \text {. } \\
\text { 'Sample } n=1109 \text {; source: Dutch National Crohn and Colitis Patient Asso- } \\
\text { ciation (CCUVN). }\end{array}$} \\
\hline
\end{tabular}


TABLE 2. Net Labor Participation Rate (Among People Age 15 to 64) of IBD Patients and Reference Groups

\begin{tabular}{|c|c|c|c|}
\hline & $\begin{array}{l}\text { Patients with IBD, } \\
2010 \%(95-\mathrm{CI})^{\mathrm{b}}\end{array}$ & $\begin{array}{l}\text { Patients with Chronic } \\
\text { Illness }^{\mathrm{c}}, 2010 \%(95-\mathrm{CI})^{\mathrm{b}}\end{array}$ & $\begin{array}{l}\text { General Dutch Working } \\
\text { Population }{ }^{\mathrm{d}}, 2010 \%\end{array}$ \\
\hline Total group weighted & 71.8 & & \\
\hline \multicolumn{3}{|l|}{ Males } & 67.1 \\
\hline 15 to 24 years & $-^{\mathrm{e}}$ & $-^{e}$ & 39.1 \\
\hline 25 to 34 years & $84.9(76.0-93.7)$ & $86.7(73.8-99.6)$ & 87.8 \\
\hline 35 to 44 years & $87.2(79.6-94.8)$ & $87.3(78.2-96.4)$ & 90.8 \\
\hline 45 to 54 years & $84.0(76.3-91.9)$ & $65.2(55.3-75.1)$ & 88.3 \\
\hline 55 to 64 years & $55.3(43.8-66.7)$ & $41.0(34.9-47.2)$ & 61.2 \\
\hline \multicolumn{4}{|l|}{ Females } \\
\hline 15 to 24 years & $58.6(45.6-71.7)$ & $55.3(40.6-70.0)$ & 36.2 \\
\hline 25 to 34 years & $83.2(78.5-87.9)$ & $75.6(66.5-84.6)$ & 79.2 \\
\hline 35 to 44 years & $75.2(69.4-81.1)$ & $73.6(66.7-80.5)$ & 74.3 \\
\hline 45 to 54 years & $71.2(64.0-78.3)$ & $49.7(41.9-57.5)$ & 68.9 \\
\hline 55 to 64 years & $44.2(34.0-54.4)$ & $23.0(18.4-27.7)$ & 36.2 \\
\hline \multicolumn{4}{|c|}{ 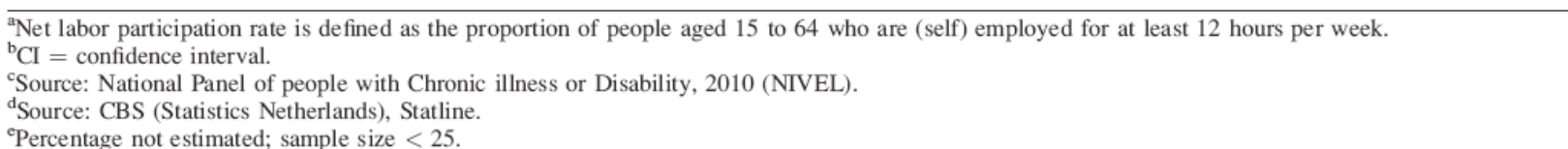 } \\
\hline
\end{tabular}

TABLE 3. Number of Hours Worked per Week: Mean (Standard Deviation) and Proportions Working 12-19, 20-34, and 35 or More Hours Among Total Groups of People Who Participate in the Labor Market ( $\geq 12 \mathrm{hpw})$

\begin{tabular}{|c|c|c|c|}
\hline & $\begin{array}{l}\text { Patients with IBD, } \\
2010, \%(95-\mathrm{CI})^{\mathrm{a}}\end{array}$ & $\begin{array}{l}\text { Patients with Chronic } \\
\text { Illness }{ }^{\mathrm{b}}, 2010 \%(95-\mathrm{CI})^{\mathrm{a}}\end{array}$ & $\begin{array}{l}\text { General Dutch Working } \\
\text { Population }^{\mathrm{c}}, \% 2010\end{array}$ \\
\hline Mean $(\mathrm{CI})$ & $31.2(30.6-31.9)$ & $30.2(29.4-31.0)$ & 34.4 \\
\hline 12 to 19 hours & 10.5 & 14.2 & 9.6 \\
\hline 20 to 34 hours & 46.9 & 44.7 & 30.9 \\
\hline 35 or more hours & 42.6 & 41.1 & 59.5 \\
\hline
\end{tabular}

\begin{tabular}{|c|c|c|c|c|}
\hline & $\begin{array}{l}\text { Patients with IBD, } \\
2010 \%(95-C I)^{\mathrm{a}}\end{array}$ & $\begin{array}{l}\text { General Dutch Working } \\
\text { Population, } 2010 \%\end{array}$ & $\begin{array}{l}\text { Patients with IBD, } \\
2010 \text { (95-CI) }\end{array}$ & $\begin{array}{c}\text { General Dutch Working } \\
\text { Population } 2010^{\mathrm{b}}\end{array}$ \\
\hline & \multicolumn{2}{|c|}{ Working full-time (35> hours per week) } & \multicolumn{2}{|c|}{ Mean number of hours worked per week } \\
\hline \multicolumn{5}{|l|}{ Males } \\
\hline 15 to 24 years $(n=4)$ & $-^{c}$ & 57.5 & $-^{c}$ & 32.4 \\
\hline 25 to 34 years $(n=56)$ & $83.9(72.0-91.5)$ & 87.2 & $37.7(35.7-39.8)$ & 39.3 \\
\hline 35 to 44 years $(n=68)$ & $83.8(73.1-90.9)$ & 88.7 & $39.1(37.2-40.9)$ & 40.7 \\
\hline 45 to 54 years $(n=74)$ & $74.3(63.3-83.0)$ & 88.0 & $36.3(34.5-38.1)$ & 40.6 \\
\hline 55 to 64 years $(n=42)$ & $54.8(39.9-68.8)$ & 76.7 & $34.5(30.9-38.1)$ & 38.4 \\
\hline \multicolumn{5}{|l|}{ Females } \\
\hline 15 to 24 years $(n=34)$ & $32.4(19.0-49.3)$ & 31.0 & $27.9(24.8-31.0)$ & 27.3 \\
\hline 25 to 34 years $(n=208)$ & $39.4(33.0-46.2)$ & 43.1 & $30.7(29.6-31.8)$ & 31.1 \\
\hline 35 to 44 years $(n=158)$ & $20.3(14.7-27.2)$ & 24.5 & $28.2(26.7-29.6)$ & 27.7 \\
\hline 45 to 54 years $(n=111)$ & $19.8(13.4-28.3)$ & 25.0 & $26.4(24.7-28.1)$ & 27.8 \\
\hline 55 to 64 years $(n=42)$ & $19.1(9.7-33.6)$ & 22.6 & $26.7(24.0-29.5)$ & 27.0 \\
\hline
\end{tabular}




\begin{tabular}{|c|c|c|c|c|c|c|}
\hline & $\begin{array}{c}0-11 \mathrm{hpw} \\
(N=277-296)\end{array}$ & $\begin{array}{l}12-19 \text { hpw } \\
(N=80-84)\end{array}$ & $\begin{array}{l}20-34 \text { hpw } \\
(N=361-374)\end{array}$ & $\begin{array}{c}35 \geq \text { hpw } \\
(N=329-340)\end{array}$ & $P$ & $\begin{array}{l}\text { Post-hoc } \\
\text { Test }\end{array}$ \\
\hline Sociodemographic characteristics: & 1 & 2 & 3 & 4 & & \\
\hline Gender $(\%)$ & & & & & $<0.001$ & \\
\hline Male & 26.3 & 9.5 & 13.6 & 54.4 & & \\
\hline Female & 73.7 & 90.5 & 86.4 & 45.6 & & \\
\hline Age (mean, SD) & $43.5(13.5)$ & $40.5(11.3)$ & $39.9(10.7)$ & $38.8(10.4)$ & $<0.001$ & 1 \\
\hline Educational level (\%) & & & & & $<0.001$ & \\
\hline Low & 12.9 & 7.1 & 3.5 & 6.3 & & \\
\hline Middle & 55.5 & 60.7 & 40.8 & 41.6 & & \\
\hline High & 31.6 & 32.2 & 55.7 & 52.1 & & \\
\hline Marital status (\%) & & & & & 0.207 & \\
\hline Married/cohabiting & 76.6 & 82.1 & 77.8 & 72.6 & & \\
\hline Single (incl. divorced, widowed) & 23.4 & 17.9 & 22.2 & 27.4 & & \\
\hline \multicolumn{7}{|l|}{ Disease characteristics: } \\
\hline Type IBD (\%) & & & & & 0.005 & \\
\hline Crohn's disease & 58.5 & 53.6 & 51.3 & 49.4 & & \\
\hline Ulcerative colitis & 34.1 & 39.3 & 46.3 & 44.4 & & \\
\hline Other & 7.4 & 7.1 & 2.4 & 6.2 & & \\
\hline Illness duration (mean, SD) & $12.2(9.9)$ & $10.1(8.2)$ & $11.2(9.5)$ & $9.5(7.6)$ & $<0.001$ & 1 \\
\hline $\begin{array}{l}\text { Currently under medical treatment } \\
\text { by GP/specialist for IBD (\%) }\end{array}$ & & & & & 0.175 & \\
\hline No & 1.01 & 2.38 & 1.07 & 2.94 & & \\
\hline Yes & 98.99 & 97.62 & 98.93 & 97.06 & & \\
\hline $\begin{array}{l}\text { Hospitalization due to IBD during } \\
\text { the last } 12 \text { months }(\%)\end{array}$ & & & & & 0.088 & \\
\hline No & 74.32 & 80.72 & 81.82 & 80.88 & & \\
\hline Yes & 25.68 & 19.28 & 18.18 & 19.12 & & \\
\hline Currently with a stoma (\%) & & & & & 0.002 & \\
\hline No & 88.18 & 95.24 & 95.19 & 94.41 & & \\
\hline Yes & 11.82 & 4.76 & 4.81 & 5.59 & & \\
\hline Currently with a pouch (\%) & & & & & 0.051 & \\
\hline No & 94.59 & 96.43 & 98.13 & 97.65 & & \\
\hline Yes & 5.41 & 3.57 & 1.87 & 2.35 & & \\
\hline $\begin{array}{l}\text { Currently using medicines prescribed } \\
\text { by a GP/specialist }(\%)\end{array}$ & & & & & 0.836 & \\
\hline No & 9.12 & 9.52 & 8.04 & 10.00 & & \\
\hline Yes & 90.88 & 90.48 & 91.96 & 90.00 & & \\
\hline $\begin{array}{l}\text { Currently using prescribed } \\
\text { dietary product }(\%)\end{array}$ & & & & & 0.234 & \\
\hline No & 92.23 & 92.86 & 95.16 & 95.59 & & \\
\hline Yes & 7.77 & 7.14 & 4.84 & 4.41 & & \\
\hline Presence of comorbidity ( $\%$ ) & & & & & $<0.001$ & \\
\hline No & 15.7 & 29.8 & 38.0 & 44.1 & & \\
\hline Yes & 84.3 & 70.2 & 62.0 & 55.9 & & \\
\hline \multicolumn{7}{|l|}{ Perceived health status: } \\
\hline Vitality (mean, SD) (0-100) & $41.8(18.9)$ & $45.1(19.5)$ & $49.8(19.2)$ & $55.3(20.0)$ & $<0.001$ & $1,2,3$ \\
\hline Pain (mean, SD) (0-100) & $62.6(24.2)$ & $68.1(20.5)$ & $72.6(22.8)$ & $76.6(22.5)$ & $<0.001$ & 1 \\
\hline Mental health (mean, SD) $(0-100)$ & $67.3(16.3)$ & $67.7(14.9)$ & $72.1(15.1)$ & $73.0(15.9)$ & $<0.001$ & 1 \\
\hline
\end{tabular}


TABLE 5. (Continued)

\begin{tabular}{|c|c|c|c|c|c|c|}
\hline & $\begin{array}{c}0-11 \mathrm{hpw} \\
(N=277-296)\end{array}$ & $\begin{array}{l}12-19 \mathrm{hpw} \\
(N=80-84)\end{array}$ & $\begin{array}{c}20-34 \mathrm{hpw} \\
(N=361-374)\end{array}$ & $\begin{array}{c}35 \geq \mathrm{hpw} \\
(N=329-340)\end{array}$ & $P$ & $\begin{array}{l}\text { Post-hoc } \\
\text { Test }\end{array}$ \\
\hline \multicolumn{7}{|l|}{ Psychological characteristics: } \\
\hline Coping (1-4) & $3.0(0.4)$ & $2.9(0.4)$ & $3.0(0.3)$ & $3.0(0.4)$ & 0.156 & \\
\hline $\begin{array}{l}\text { Perceived personal control } \\
\text { IBD (mean, SD) }(1-10)\end{array}$ & $5.1(2.2)$ & $5.1(1.9)$ & $5.4(2.1)$ & $5.9(2.2)$ & $<0.001$ & $1,2,3$ \\
\hline Perceived treatment control IBD (1-10) & $7.2(2.0)$ & $7.4(1.6)$ & $7.4(1.6)$ & $7.4(1.7)$ & 0.558 & \\
\hline Illness concern $(1-10)$ & $6.0(2.1)$ & $5.6(2.0)$ & $5.6(2.1)$ & $5.3(2.3)$ & 0.002 & 1 \\
\hline Illness coherence $(1-10)$ & $7.1(2.0)$ & $7.3(1.8)$ & $7.0(2.0)$ & $7.0(1.9)$ & 0.633 & \\
\hline \multicolumn{7}{|l|}{ Social/environmental characteristics } \\
\hline \multicolumn{7}{|l|}{ Experienced lack of: } \\
\hline $\begin{array}{l}\text { Problem oriented emotional } \\
\text { support }(6-18)\end{array}$ & $8.3(2.8)$ & $8.5(2.9)$ & $8.0(2.5)$ & $7.8(2.6)$ & 0.043 & \\
\hline Esteem support (4-12) & $5.2(1.8)$ & $5.3(1.8)$ & $4.9(1.4)$ & $5.0(1.6)$ & 0.022 & \\
\hline Instrumental support (6-18) & $7.4(2.0)$ & $7.2(1.7)$ & $7.0(1.6)$ & $7.0(1.8)$ & 0.077 & \\
\hline Informative support (3-9) & $3.9(1.3)$ & $3.7(1.1)$ & $3.7(1.1)$ & $3.7(1.2)$ & 0.282 & \\
\hline
\end{tabular}


TABLE 6. Significance of Characteristics for the Prediction of the Number of Hours Worked per Week by IBD Patients (Reference Group: Patients Working $35 \mathrm{Hrs}$ or More) $(N=1024)$

\begin{tabular}{|c|c|c|c|c|c|c|}
\hline & \multicolumn{2}{|c|}{$0-11 \mathrm{hpw}$} & \multicolumn{2}{|c|}{ 12-19 hpw } & \multicolumn{2}{|c|}{ 20-34 hpw } \\
\hline & $\mathrm{B}^{\mathrm{a}}$ & $\mathrm{RRR}^{\mathrm{b}}$ & B & RRR & $\mathrm{B}$ & RRR \\
\hline \multicolumn{7}{|l|}{ Sociodemographic characteristics } \\
\hline Female (ref. male) & $1.38 * * *$ & $3.96 * * *$ & $2.68 * * *$ & $14.62 * * *$ & $2.22 * * *$ & $9.22 * * *$ \\
\hline Age & $0.04 * * *$ & $1.04 * * *$ & $0.03 *$ & $1.03 *$ & $0.03 * *$ & $1.03 * *$ \\
\hline \multicolumn{7}{|l|}{ Educational level (ref. high) } \\
\hline Low & -0.11 & 0.90 & 0.64 & 1.90 & 0.52 & 1.69 \\
\hline Middle & -0.65 & 0.52 & -0.07 & 0.93 & 0.68 & 1.98 \\
\hline Married/cohabiting (ref. single) & -0.02 & 0.98 & 0.55 & 1.73 & 0.05 & 1.05 \\
\hline \multicolumn{7}{|l|}{ Disease characteristics } \\
\hline \multicolumn{7}{|l|}{ Type IBD (ref. Crohn's disease) } \\
\hline Ulcerative colitis & 0.02 & 1.02 & 0.07 & 1.07 & 0.24 & 1.27 \\
\hline Other type of IBD & 0.19 & 1.21 & 0.57 & 1.77 & $-1.10^{*}$ & $0.33 *$ \\
\hline Illness duration & 0.02 & 1.02 & 0.00 & 1.00 & $0.03 *$ & $1.03 *$ \\
\hline $\begin{array}{l}\text { Currently under medical treatment by } \\
\text { GP/specialist for IBD }(\%)\end{array}$ & 0.87 & 2.38 & 0.91 & 2.49 & 1.00 & 2.72 \\
\hline $\begin{array}{l}\text { Hospitalization due to IBD during the } \\
\text { last } 12 \text { months }(\%)\end{array}$ & -0.13 & 0.88 & -0.12 & 0.88 & -0.05 & 0.95 \\
\hline Currently with a stoma (\%) & $0.76^{*}$ & $2.13 *$ & -0.12 & 0.89 & 0.01 & 1.01 \\
\hline Currently with a pouch $(\%)$ & $1.38 *$ & $3.96 *$ & 1.21 & 3.35 & 0.19 & 1.21 \\
\hline $\begin{array}{l}\text { Currently using medicines prescribed } \\
\text { by a GP/specialist }(\%)\end{array}$ & -0.08 & 0.92 & -0.18 & 0.83 & -0.07 & 0.93 \\
\hline Currently using prescribed dietary product: $(\%)$ & 0.17 & 1.18 & 0.60 & 1.83 & -0.12 & 0.89 \\
\hline Presence of comorbidity & $0.84 * * *$ & $2.32 * * *$ & -0.07 & 0.93 & -0.17 & 0.84 \\
\hline \multicolumn{7}{|l|}{ Perceived health status } \\
\hline Vitality & $-0.02 * * *$ & $0.98 * *$ & -0.01 & 0.99 & -0.01 & 0.99 \\
\hline Bodily pain $^{c}$ & $-0.01 *$ & $0.99^{*}$ & -0.01 & 0.99 & 0.00 & 1.00 \\
\hline Mental health & 0.00 & 1.00 & -0.02 & 0.98 & 0.00 & 1.00 \\
\hline \multicolumn{7}{|l|}{ Psychological characteristics } \\
\hline Proactive coping & -0.00 & 1.00 & -0.29 & 0.75 & -0.02 & 0.98 \\
\hline Perceived personal control & $-0.11 *$ & $0.90^{*}$ & -0.11 & 0.90 & -0.09 & 0.91 \\
\hline Perceived treatment control & 0.08 & 1.08 & 0.06 & 1.06 & 0.01 & 1.01 \\
\hline Illness concern & 0.02 & 1.02 & -0.09 & 0.91 & 0.01 & 1.01 \\
\hline Illness coherence & 0.01 & 1.02 & 0.07 & 1.08 & -0.02 & 0.98 \\
\hline \multicolumn{7}{|l|}{ Social/environmental characteristics } \\
\hline \multicolumn{7}{|l|}{ Experienced lack of: } \\
\hline Problem oriented emotional support & -0.02 & 0.98 & 0.07 & 1.07 & 0.06 & 1.06 \\
\hline Esteem support & 0.05 & 1.05 & 0.10 & 1.10 & -0.09 & 0.92 \\
\hline Instrumental support & -0.07 & 0.93 & -0.07 & 0.94 & -0.03 & 0.97 \\
\hline Informative support & -0.01 & 0.99 & -0.24 & 0.79 & -0.08 & 0.92 \\
\hline
\end{tabular}

